Jnl. Soc. Pol. (2023), 52, 1, 85-106 C The Author(s), 2021. Published by Cambridge University Press. This is an Open Access article, distributed under the terms of the Creative Commons Attribution licence (http:// creativecommons.org/licenses/by/4.0/), which permits unrestricted re-use, distribution, and reproduction in any medium, provided the original work is properly cited. doi:10.1017/S0047279421000428

\title{
Subsidized Household Services and Informal Employment: The Belgian Service Voucher Policy
}

\section{STEF ADRIAENSSENS (D), TOBIAS THEYS, DIETER VERHAEST (D) AND NICK DESCHACHT}

KU Leuven, Faculty of Economics and Business, Research Centre for Economics, Warmoesberg 26, 1000 Brussels, Belgium emails: stef.adriaenssens@kuleuven.be; tobias.theys@kuleuven.be; dieter.verhaest@kuleuven.be; nick.deschacht@kuleuven.be

\begin{abstract}
Labour markets for personal and household services (PHS) are rife with informal employment. Some policies aim to combat informality in PHS with subsidized service vouchers, but their effects are poorly documented. This contribution evaluates the Belgian service vouchers (1) documenting their formalization effectiveness, and (2) accounting for the persistence of informal employment. To this end, we exploit several types of data and methods.

A first analysis, based on Eurobarometer data, brings in evidence that informal PHS purchased were approximately halved under the policy introduced in 2001. Second, a discrete choice experiment shows that households prefer formal employment, including those that currently employ informally. Third, a survey in the Brussels metropolitan area shows that the persistence of informal employment lies in the relationship of informal employers with their domestic, from whom they are not willing to part. They nevertheless intend to switch to formal employment in the case of turnover. One thus expects partially delayed effects of formalization policies in general, and of the service voucher system in particular. Overall, these results are in line with Portes' claim that informality is facilitated by strong social relationships, and by differences in price and transaction costs.
\end{abstract}

\section{Twitter abstract}

Belgian service vouchers are found to reduce informal domestic work substantially. Our evidence suggests surviving informality is due to strong relationships between household and domestic.

Keywords: personal and household services; domestic work; informal and underground economy; service voucher; policy evaluation; social relationships

\section{Introduction}

The management of the household, ranging from cleaning and childcare over home maintenance to the provisioning of food, has always had an intriguing relationship with market life for several reasons. First, households keep on 
providing many of these outcomes economic coordination that can hardly be described as 'markets' (Polanyi, 1957): the internal provision by household members, reciprocal systems of cooperation and support, and so forth (White and Williams, 2016). If, for instance, in a given country one were to compare the aggregate time spent cleaning by household members versus by paid workers, the former would probably surpass the latter. Second, within the labour or service market, 'personal and household services' (PHS) have a universally recurring feature. In virtually every country, PHS stand out for the high incidence of informal and off-the-books exchanges.

Recently, policies regarding PHS, and in particular attempts to deter informal practices in these markets, have received considerable attention in several European countries. The explicit goals of these policies are to increase employment (Leduc and Tojerow, 2020), to support the work-life balance of employing households (Craig and Baxter, 2016; Kornrich and Roberts, 2018; Morel, 2015; Raz-Yurovich and Marx, 2018, 2019), and to tackle informal employment (Farvaque, 2015; Williams, 2018), which may, in turn, result in better working and living conditions. This latter point is not unimportant. To the extent that formal work provides access to protection and secondary and tertiary benefits, formalization tends to have important effects on the quality of life of workers (Hobson et al., 2018).

Globally, the labour market for domestic employment is seen as a hotbed of informal economic activities (Lutz and Palenga-Möllenbeck, 2010). Informality is rooted in phenomena related to market conditions, the polity, and the position of individuals in society. Throughout the various theoretical and disciplinary approaches of informal activities, some elements recur as relevant causal factors. In this contribution, we focus on two central hypothetical factors from the socalled 'Portes model' of informal economic activities (Portes, 2010; Portes and Haller, 2005). This model predicts that taxation levels and the regulatory burden will increase the tendency to go informal. In the interpersonal sphere, on the other hand, it predicts that social connections might facilitate access to informal work, because it substitutes information access and protection from the formal sphere. A sizeable number of European countries has developed measures that explicitly aim to tackle informal employment in PHS while fostering (formal) employment growth. Most of these policies rely on a mix that aims to decrease the price, search costs, and the administrative burden of hiring a formal domestic worker by offering subsidies, tax cuts, and accessible recruitment of domestic workers supplying household services. One of the policies to combat informal employment incentivizes households to purchase domestic services through service vouchers, facilitating matching and subsidizing the wage cost. Strangely enough, most evaluations assess employment effects without estimating informal employment. To contribute to filling this gap in the literature, this contribution hypothesizes that the reduction in wage, search, and administrative costs 
resulting from the service voucher scheme, reduces informal employment for domestic workers and that ongoing social relations account for the surviving informal employment.

Our analyses are based on the Belgian service voucher scheme that was introduced in 2001. We rely on three data sources: a Eurobarometer survey in the European Union, our own survey of households in the Brussels urban area, and a discrete choice experiment with the same group. Analysis of the Eurobarometer data brings in evidence that the Belgian service voucher scheme has indeed been effective at reducing informal employment. Nevertheless, a significant part of domestic employment remains informal. Results of a choice experiment then document households' willingness to pay for formal employment, indicating that the remaining informal employment is not due to the preference of households for off-the-books transactions. They consistently prefer formal employment, even among informal employers. We then bring in evidence that the most likely factor accounting for the persistence of informal employment is the personal relationship between some households and their housekeeper, preventing them from switching to formal employment. Original survey data in Brussels show that households employing an informal domestic are less likely to stick to this employment status in the case of turnover. These results are consistent with the expectation of delayed effects, and thus a further expected decrease of informal domestic employment in the future.

\section{Background and hypotheses}

\subsection{Accounting for informality}

Activities are informal when legal by law, but with some transgression of formal regulation in the provision of the commodity or service (Adriaenssens et al., 2015; Feige, 1990). Portes' framework accounts for informal economic transactions with a set of institutional and individual elements: economic incentives, institutions, and relational elements (Portes, 1994, 2010; Portes and Haller, 2005). It builds a three-stage framework, with the economic costs and benefits of going formal through regulation and taxation at the first level, their enforcement as the second, and the levels of wiring and trust between people as the third element. In this contribution, we focus on the first and third elements.

First of all, the framework predicts that regulation and taxation foster informality. Regulation creates the potential of not complying, and that creates a potential gain from not complying. That effect involves two mechanisms. First, regulation and taxation involve costs incurred on the transaction. Costs may differ substantially in their nature, size, and prevalence: administrative paperwork, lack of flexibility, loss of income, price increases. Overall, the empirical literature seems to support that taxes and regulations push agents out of formal transactions and into informality or evasion (Fisman and Wei, 2004; 
Loayza, 1996; Marion and Muehlegger, 2008; Prado, 2011). The case of tax rates is theoretically more complicated, with the central neoclassical theories proving that rising tax levels have an ambiguous (Allingham and Sandmo, 1972) or a negative effect on evasion levels (Yitzhaki, 1974). We use this prediction to hypothesize that the wage subsidies in the service voucher scheme will reduce incentives for informal employment in PHS. It should, conversely, be noted that more regulation and a higher tax burden do not necessarily increase informality. Formality indeed entails costs (e.g. taxes, or a lack of flexibility), but also provides access to formal institutions that may allow reducing search and enforcement costs: for instance, through access to legally prescribed guarantees. In the case of PHS in Belgium, we predict that the reduction in search costs in the formal system will also reduce the attractiveness of informal employment.

Another crucial element Portes brings in is how social connections and social trust function as facilitating mechanisms of informal activities. Generally, this means that both strong social connections and mutual social trust decrease the need for access to formal enforcement and coordination mechanisms. Portes thus expects, ceteris paribus, that higher levels of strong social connections foster informal activities. This hypothesis, if verified, might provide a mechanism as to why formalization policies often are by and large not effective (see e.g. Floridi et al., 2020): the embeddedness in strong social relationships makes informal institutions somehow resistant to formalization. There is some empirical support for this conjecture that social bonds foster informal transactions (Adriaenssens and Hendrickx, 2015; Annen, 2013; Lindström, 2005). Applied to the case of domestic employment, we assume that an ongoing employment relationship somehow resists the service voucher policy to the extent that there is a stronger personal relationship between the employing household and the domestic worker. If we find support for this hypothesis, the policy lesson would be that a significant time lag may occur between the implementation of the policy and its potential effects.

\subsection{Social policies tackling the informal economy in domestic work}

Domestic employment is on the rise, growing by 6\% between 1995 and 2010 in advanced economies, to 3.6 million workers (ILO, 2013), resulting in domestic work as a significant proportion of the European working population (Abrantes, 2014). This rise in domestic employment takes place against a strong incidence of informal arrangements in personal and household services (PHS) (Estévez-Abe and Hobson, 2015; Pisani, 2005; Pisani et al., 2008). Alternatively, one could state that a large share of informal labour consists of domestic services: in $2013,32 \%$ of respondents of the active age, who reported to have supplied informal services or goods, admitted to have supplied domestic work (European Commission, 2013a). This may mean that cited statistics underestimate the proportion of paid domestics because they typically rely on official employment figures. 
Several European countries developed a policy to facilitate employment in domestic services, usually making these services more easily available to either all or targeted households, often with a combination of tax deductions and service vouchers (Kvist, 2012). France pioneered systems where households buy vouchers to pay for PHS, with a tax credit (Devetter and Jany-Catrice, 2012; Ledoux et al., 2021; Windebank, 2007). Belgium developed a similar service voucher scheme for PHS in 2001, combined with tax credits. The structural difference with the French is the Belgian trilateral system. It means that firms and non-profits are accredited and compete to provide household services, sending out domestic workers to the households. This three-party system allows for a considerable reduction of search costs for the households, and probably increases their freedom to choose (Andersen, 2020). Apart from these beneficial effects in choice, search and coordination costs, the trilateral system explicitly aims to create more formalized relationships between the household and their domestic worker (Devetter and Rousseau, 2009). The system depends both on wage and firm subsidies. The vouchers are sold at a discounted price, and participating households receive an income tax deduction.

The service vouchers have been highly successful, as measured by the number of workers, service vouchers used, and households participating. In 2015, the voucher scheme employed 153,301 workers (Gerard et al., 2014; Schooreel and Valsamis, 2017), a fivefold increase of the share of service voucher domestics in formal Belgian employment in a decade (0.7\% in 2005 to $3.4 \%$ in 2015). It should be noted that the policy requires considerable public means, with a gross subsidy of slightly over $70 \%$ of the total cost. The central stated goals of the policy were: (1) the improvement of the labour market participation of women and low-skilled; (2) a reduction of informal labour in domestic services; and (3) meeting unmet needs in domestic services (Belgische Kamer van Volksvertegenwoordigers, 2000-2001). Not every stated policy goal has received the same scrutiny in evaluation, but the existing contributions allow for a partial picture at least.

First of all, Raz-Yurovich and Marx (2018) find a marked effect in terms of employment of low-skilled women. This finding is substantiated by research by Desiere and Goesaert (2019), estimating a net employment effect of up to $80 \%$ in full-time equivalents. Leduc and Tojerow (2020) find that starting to work in the service voucher scheme increases the probability to work five years later by $42 \%$.

The second series of evaluations have pointed to weaknesses in effectiveness and efficiency. Some criticized the system's lack of cost-efficiency (Pacolet et al., 2010). Marx and Vandelannoote (2015) infer from the increasing job tenure of service voucher workers that the system has become less important as a stepping stone to non-subsidized employment. This in itself might also be due to the recency of the policy, a logical consequence of the aim of stable employment in the programme. If a certain group is admitted into a new policy and there is no automatic turnover after a period, average seniority would always increase 
somehow. This would even be the case with stable job dynamics. Nevertheless, Leduc and Tojerow (2020) support the conjecture that the stepping stone hardly functions. They find that the employment effect is solely driven by employment within the subsidized voucher sector, suggesting that service voucher jobs indeed hardly serve as stepping stones into non-subsidized jobs. Also, recruitment among the weaker profiles on the labour market seems to dwindle, probably due to the rising market share of for-profit firms (from $20 \%$ in 2004 to $63 \%$ in 2012). Defourny et al. (2010) also find that for-profit firms spend less on formal training than not-for-profit providers.

Finally, some studies have pointed to ongoing problems in recruitment due to ethnic discrimination and language mismatch. Households have strong preferences for service provision in their own language, which is not always available, and against workers of Maghreb origin (Theys et al., 2020). This is in line with findings from in-depth interviews (Bosmans et al., 2016). Nevertheless, the service voucher scheme also facilitates recent migrants' access to formal employment (Godin, 2013).

This contribution documents the effectiveness of the programme in the reduction of informal employment, probably the biggest empirical gap in the PHS literature. This lack of attention to the effects of labour market policies on informality is a more general problem. One usually estimates effects on formal wages and formal employment, while the interaction with informal labour markets is hardly discussed (for instance, Card et al., 2010), although some research does account for the substitution between informal and formal labour (Deidda et al., 2015).

To our knowledge, the only empirical research to test this policy goal is a self-report of voucher users and employees of prior engagement in informal domestic work (Peeters et al., 2008, 2009): a significant minority of $17 \%$ of households and $3.1 \%$ of the service voucher employees reported informal household services before switching to the formal system (Peeters et al., 2008, 2009). Whether this gap between households' and workers' self-reported history of informal employment results from differences in social desirability bias or domestic work mainly being a transitory job to other occupations, is unclear. However, even if this points to decreasing informal employment, it cannot necessarily be attributed to the service voucher scheme. It does show that informal employment survives in PHS. In the remainder of this paper, we test whether and why households still employ a housekeeper informally. We first study the extent of informal employment through a household survey in Brussels (see section 2). Approximately one in seven respondents employing a domestic (13.9\%) admitted that they did so off-the-books. This probably is an underestimate: some respondents shy away from reporting this due to social desirability bias, and unit or item nonresponse (Kleck and Roberts, 2012). The important conclusion nevertheless is that a significant minority of the households still employ a domestic worker informally. 
The persistence of informal employment is hard to explain through differences in price or search costs: the service voucher policy leads to a lower market price for a formal domestic worker, and search and coordination costs are low too. Therefore, we test several alternative explanations.

We start by testing the most evident explanation: the policy is ineffective. This hypothesis is tested with the help of a European survey documenting purchases of informal services. We design a test based on a design similar to a differencein-differences approach, exploiting the detailed information that is collected about the kind of domestic service purchased. We distinguish between domestic services that are covered by the voucher programme, and the domestic services not covered by the programme - the latter are used as controls. We compare this difference in informal purchases between activities in Belgium with the difference in informal purchases between the same activities in other EU countries.

Second, a strong preference by households for informal domestic employment might account for its survival. We test this conjecture with a discrete choice experiment where households can choose between formal and informal employment, net from any price-effect. To study whether preferences for formal employment are heterogeneous between employers, we compare the preferences of formal and informal employers.

Third, we test the hypothesis that the survival of informal employment can be attributed to the personal bond between the household and the worker, creating some stickiness. If, for one reason or another, it is hard to regularize the employment relationship with the housekeeper actually working for the household, and the employers and/or the workers value the employment relationship, they may be more willing to continue informal employment. If this is the case, informal employers should prefer to change the employment status when they hire a new worker. This explanation is explored with the help of a household survey measuring the repeat intention of the employment status in case of turnover. If the quality of the personal relationship with the housekeeper indeed explains the stickiness of informality, then they would be inclined to change to formal employment status when they have to hire a new worker, net of their satisfaction with the actual services provided.

To sum up, we state the following hypotheses:

1. The service voucher scheme reduces informal work in personal household services covered by the system;

2. Households' preference for formal employment:

a. Households eligible for employment of a domestic worker, prefer formal over informal employment

b. Employers of an informal domestic worker prefer formal over informal employment; 
TABLE 1. Share of individual respondents who declare buying informal services

\begin{tabular}{|c|c|c|c|c|c|c|}
\hline \multirow[b]{2}{*}{ Type of service } & \multicolumn{3}{|c|}{ Belgium } & \multicolumn{3}{|c|}{ Other countries } \\
\hline & Frequency & Sample size & Percent & Frequency & Sample size & Percent \\
\hline \multicolumn{7}{|l|}{ Covered by SVS } \\
\hline Cleaning & 16 & 985 & $1.62 \%$ & 508 & 25157 & $2.02 \%$ \\
\hline Ironing & 5 & 985 & $0.51 \%$ & 111 & 25046 & $0.44 \%$ \\
\hline \multicolumn{7}{|c|}{ Not covered by SVS } \\
\hline Gardening & 19 & 985 & $1.93 \%$ & 337 & 24820 & $1.34 \%$ \\
\hline Home repairs & 54 & 985 & $5.48 \%$ & 1080 & 24077 & $4.29 \%$ \\
\hline
\end{tabular}

3. Informal work arrangements are likely to end in the case of job turnover of the informal domestic worker.

\section{Data and specifications}

To test the hypotheses developed in the previous section, we make use of a Eurobarometer dataset on informal purchases in the EU, and an original survey questionnaire (including a choice experiment) administered with a sample of households in the Brussels metropolitan area.

\subsection{EU-survey of informal activities}

The first hypothesis, predicting that the Belgian service voucher policy reduces informal work, is tested with the help of a large-scale European survey (Eurobarometer number 79.2). The fieldwork was conducted in 2013 (European Commission, 2013a) and documents undeclared work and consumption in the 27 then-members of the EU, and Croatia. The sample contains over 27,000 respondents (around 1,000 in each country). Respondents were asked whether they purchased informal goods or services in the past year, and then indicated which, choosing from a list of 15 types. Our main analysis distinguishes between services that are covered by the service voucher programme in Belgium (cleaning and ironing clothes) and the two services that are most often reported to be purchased informally but that are not covered by the Belgian programme (home repairs and gardening). Table 1 shows the number of respondents in the Eurobarometer data that report purchasing informal services in Belgium and other countries - both in the types of services covered by the Belgian service voucher scheme (cleaning and ironing) and the main services not covered by the scheme (gardening and home repairs).

We estimate the impact of the Belgian service voucher policy on the use of informal services, by comparing the use of these informal services covered under 
the service programme in Belgium with the use in other countries, after controlling for country-differences in the use of informal services in other activities (i.e. home repairs and gardening). More formally, we estimate the following Linear Probability Model (Angrist and Pischke, 2009):

$$
y_{i j}=\alpha+\beta \cdot B E_{i}+\gamma \cdot d_{j}+\tau \cdot B E_{i} \times d_{j}+\varepsilon_{i j}
$$

where $y_{i j}$ is a binary variable indicating whether respondent $i$ purchased domestic service $j$ informally; $B E_{i}$ is a dummy indicating whether respondents live in Belgium and $d_{j}$ is a dummy indicating whether the domestic service is covered by the service voucher scheme. Because the elementary unit of our dataset is the service purchased, the same respondent is clustered in a number of observations. For this reason, the standard errors on the estimated coefficients are corrected for clustering at the level of the individual respondents. As is clear from the regression equation, we essentially adopt a difference-in-differences approach, where the coefficient of the interaction term $(\tau)$ estimates the impact of the Belgian service voucher policy on the use of informal services. However, the estimated impact does not compare the outcome under the Belgian policy to a counterfactual situation of "no policy" but to an average situation in other EU countries. After all, many countries have some policies in place to stimulate formal employment. For instance, France, Germany, Italy, and Austria also have policies with service vouchers or similar measures such as social security or tax reductions, but the involved budgets are vastly smaller (European Commission, 2013b; ILO, 2013).

To test the robustness and the validity of the estimates, we also run some alternative specifications and a placebo test. First, the robustness of the findings is checked by adding a list of control variables to the model, inspired by an empirical test of the Portes model on European data (Adriaenssens and Hendrickx, 2015). These control variables contain demographic, family, and work-related characteristics. Second, we check whether the results are not driven by ironing services, which only represent a small fraction of the activities subsidized by the service vouchers in Belgium. In that robustness check, we drop ironing activities from the sample. Third, a placebo test is carried out to show that no effect can be observed where no effect is to be expected: we do this by repeating the analysis on the purchase of informal home repairs, an activity that is not subsidized by the service voucher policy. In this placebo test, the sample is limited to home repairs and gardening activities and $d_{j}$ is re-defined to indicate home repairs.

\subsection{Household survey and stated choice experiment}

Beforehand, it should be noted that the sampling frame consists of households in the Brussels metropolitan area, evenly divided between the Brussels-Capital Region and the periphery in the Flemish Region. In terms of 
policy, these respondents thus belong to two of the three regional authorities (Brussels and Flanders) that develop the voucher policy, so that the service voucher schemes may differ somehow. Concurrently, it should be clear that this sample is not a random sample of the Belgian population, but is more urbanized and diverse.

The data collection for the own household survey and stated choice experiment consisted of three waves. We collected in sampled regions in the Brussels metropolitan area (Belgium). The area under study thus consisted of the Brussels-Capital Region and the municipalities contiguous to it. Language use and socio-economic features differ strongly between the urban centre and the periphery, so we selected two equal samples. Because of these aims, sampling was organized in a two-stage sample, with the neighbourhood as the first stage, and a random sample of households as the second. In order to limit sampling bias (Lavallée, 2007), the neighbourhood was sampled at the smallest geographic level possible: the statistical sector. We selected 50 of these sectors in the metropolitan area.

The probability of employing a domestic worker is strongly related to household income. The increase of domestic employment due to the service voucher policy has enabled higher and middle-income households to hire PHS (Marx and Vandelannoote, 2015). First-stage units were therefore selected on a probability proportional to the average pre-tax income in the sector. The sampling probability was ordered per quintile, with a zero probability for the first quintile.

In each unit, fieldworkers started by contacting a randomly attributed address and subsequently contacted every fourth household, with the next dwelling as a replacement in the case of uninhabited dwellings or non-response. The two initial survey waves (April-June 2015 and April-May 2016) involved face-to-face interviews. In the selected statistical sectors that were not yet covered in the previous stage, a postal survey was distributed in the third wave, at the start of 2017. Every third household was invited to fill in the survey, on paper or online.

The questionnaires, in French or Dutch, consisted of three parts: sociodemographic questions, the stated choice experiment, and a more elaborate survey for the respondents that employed a domestic worker. In the next sections, we discuss the experiment and the questionnaire separately.

\subsubsection{Discrete choice experiment}

Hypotheses $2 \mathrm{a}$ and $2 \mathrm{~b}$ state that, controlling for the price of services, households have a preference for formal employment, in general (hypothesis 2a), and also households that employ a domestic worker informally (hypothesis $2 \mathrm{~b}$ ). We test whether households are willing to pay a surplus price for formal 
employment with a discrete choice experiment (DCE), originally developed by Louviere and Hensher, 1982). A DCE elicits stated preferences and is especially suited in situations where revealed preferences are hard to discover. Respondents are asked to choose between versions of a product or service, described by several attributes with different levels. In the case of this research, each choice card consisted of two profiles of domestic workers, describing them by their attributes, and an opt-out alternative, in case none of the options are preferred. The theory behind discrete choice experiments assumes respondents choose the alternative that gives them the highest utility in the light of their preferences.

In our experiment, survey respondents who either currently, or in the past, employ(ed) a domestic worker, or are sufficiently interested in hiring one, were asked to choose between two profiles of housekeepers, or decide to choose none of them. With regard to the choice experiment, the first wave was used as a pilot study to improve the design (in the survey analysis, the first wave was included, though). In the ensuing waves, 376 respondents participated in the choice experiment, choosing 8 times between two profiles or an opt-out option. The experiment served the double purpose of documenting linguistic preferences by households and analysing the preference for formal employment. The former problem, and a more extensive discussion of the experimental design, are discussed in another paper (Theys et al., 2020). The latter study and the regressions reported here differ in samples: in this contribution we use the full sample; but the language research was limited to Dutch- and French-speaking households. The studies also differ in the design and specific interactions tested (cf. infra).

Each profile is described by five attributes: price, employment status, ethnicity, age, and the worker's language skills. It is important to note that, by including a measure for ethnicity, we ensure the employment status does not act as a potential proxy for ethnicity, through which respondents might link informal employment to an immigrant background. The employment status has three levels: informal employment, service vouchers without the tax deduction, and vouchers with a tax deduction of $30 \%$ (the current level of tax deduction in Flanders; it is only $15 \%$ in the Brussels-Capital Region). Price has 5 levels, ranging from $€_{4}$ to $€_{15}$. The price on the Belgian market for voucher subsidized services is $€ 9$ before tax deduction.

The linear combination of these attributes with several levels each leads to an unmanageable number of potential different profiles. Several methods exist to limit the number of choice cards while keeping the validity of the experiment intact. We used the software program Ngene (ChoiceMetrics, 2014) to get a D-efficient fractional design (Rose et al., 2008) with 24 choice cards in three blocks.

The choices are analysed using a conditional logit model, isolating the utility of different levels of all attributes that describe the domestic worker. 
Apart from the attributes, we add an alternative-specific constant (ASC) to each profile. These ASCs measure whether choosing one of the profiles is preferred over opting out and capture the impact of the reference level of the dummies and any unobserved characteristics.

We estimate a base model (five attributes), and an extended model with interaction effects between the employment status and the actual status of the employment relationship added (formal, informal, or currently not employing a housekeeper). This extension allows us to test whether the (dis)taste for informal employment status differs between formal and informal employers.

\subsubsection{Questionnaire survey}

We test hypothesis 3 with the questionnaire data, checking whether informal employers intend to hire a domestic worker informally again, in the case of turnover of the current employee. In the questionnaire, a number of items measure the employment status (with indirect questions), the relationship and communication with the domestic worker, and one gauging whether the household would employ a domestic in the same status if the present domestic worker were to leave the job. This repeat intention is measured with a 5-point Likert scale, ranging from 'highly unlikely' to 'most likely' ( $\bar{X}=4.4$; $\mathrm{SD}=0.43$ ). Hypothesis 3 is tested by regressing this repeat intention of the employment status on the status of the employment relation (informal versus formal).

The most important control variable in this regression is the reported satisfaction with the services by the domestic worker. This allows us to isolate the specific evaluation of the employment relation, without consideration of the perceived quality of the service from the current domestic worker.

We further use the same household and respondent features as in the Eurobarometer regression as controls (see section 2.1). Additionally, we add the household size as a control, because the demand for household help is also associated with the presence of a partner and live-in children (Craig and Baxter, 2016; de Ruijter et al., 2005). We run a linear model with robust standard errors.

In the results section, we also test the difference in mean seniority between informal and formal domestic workers. Given the difference in sample size and the uneven variance, we use Welch's t-test.

\section{Results}

As indicated, some informal employment survives in the market for domestic work. This is somewhat surprising, given the comparative advantage of the service voucher scheme in price and search costs. The question then is what causes this survival of informal employment. First, we test whether the service voucher policy has been successful in reducing informality in the domestic 
TABLE 2. The impact of the Belgian service vouchers on informal domestic services

\begin{tabular}{|c|c|c|c|c|}
\hline & \multirow{2}{*}{$\frac{\text { Model } 1}{\text { Base }}$} & \multirow{2}{*}{$\frac{\text { Model } 2}{\text { With controls }}$} & \multirow{2}{*}{$\frac{\text { Model } 3}{\text { Cleaning only }}$} & \multirow{2}{*}{$\frac{\text { Model } 4}{\text { Placebo }}$} \\
\hline & & & & \\
\hline Constant & $0.028^{* * * * *}$ & $0.009^{* * * *}$ & $0.028^{* * * *}$ & $0.013^{\text {***** }}$ \\
\hline Belgium & $0.009^{* *}$ & $0.009^{* *}$ & $0.009^{* *}$ & 0.006 \\
\hline Voucher scheme & $-0.016^{* * * *}$ & $-0.016^{* * * *}$ & $-0.008^{* * * *}$ & $0.030^{* * * *}$ \\
\hline Interaction effect: & $-0.011^{* *}$ & $-0.011^{* *}$ & $-0.013^{* *}$ & 0.006 \\
\hline \multicolumn{5}{|l|}{ Belgium * Voucher } \\
\hline Control variables & No & Yes & No & No \\
\hline Person-services (n) & 104,568 & 104,568 & 78,426 & 52,284 \\
\hline
\end{tabular}

${ }^{*} p<.1 ;{ }^{* *} p<.05 ;{ }^{* * *} p<.01 ;{ }^{* * * *} p<.001$.

Linear probability models with the dependent variable measuring whether a respondent has bought a service informally or not. An observation reflects a combination of a consumption activity in one individual. Standard errors are clustered at the level of individual respondents. Model 2 includes controls for age, education, gender, subjective class, partner, urbanization, and activity (non-active, employee, or self-employed).

Model 4 repeats the analysis for the purchase of informal home repair services (placebotreated group).

labour market. Then, three potential hypotheses are tested to account for the remaining informal employment.

\subsection{Service vouchers reduce informality}

The first regressions aim to test whether the Belgian service vouchers reduced informal work (hypothesis 1). We do so by exploiting the differences in the use of informal services, covered by the service voucher scheme or not, purchased by Belgian respondents compared to those in the rest of the EU.

The linear probability models below (Table 2) show that Belgian respondents have a higher propensity to purchase informal services, except for the areas covered by the service voucher scheme. The impact of the system on the use of informal services is negative and statistically significant. Moreover, the effect size is substantial: the main analysis (model 1) suggests that the programme halved the use of informal work $(-0.011 /[0.028+0.009-0.016])$, albeit with a substantial confidence interval.

The other columns in Table 2 confirm the robustness to alternative specifications and present a placebo test. Adding control variables for demographic, family, and work-related characteristics does not alter the estimated effect (model 2). Limiting the analysis to cleaning activities only (model 3), the main activity for service vouchers, suggests that the policy impact is even larger. The placebo test (model 4) repeats the analysis to estimate the impact of the Belgian 
TABLE 3. Preference for formal employment in the discrete choice experiment

\begin{tabular}{|c|c|c|c|c|}
\hline & \multicolumn{2}{|c|}{ Model 1} & \multicolumn{2}{|c|}{ Model 2} \\
\hline & Coefficient & S.E. & Coefficient & S.E. \\
\hline \multicolumn{5}{|l|}{ Employment status (ref.: informal employment) } \\
\hline Service vouchers with tax deduction & $1.669^{* * *}$ & 0.105 & $1.814^{* * *}$ & 0.132 \\
\hline Service vouchers without tax deduction & $0.777^{* * *}$ & 0.099 & $0.912^{* * *}$ & 0.122 \\
\hline Price & $-0.129^{* * *}$ & 0.012 & $-0.130^{* * *}$ & 0.012 \\
\hline ASC 1 & $1.492^{* * *}$ & 0.164 & $1.505^{* * *}$ & 0.163 \\
\hline ASC 2 & $1.535^{* * *}$ & 0.178 & $1.548^{* * *}$ & 0.177 \\
\hline \multicolumn{5}{|c|}{ Interaction effects (ref.: currently employing a formal domestic worker) } \\
\hline $\begin{array}{l}\text { Informal worker }{ }^{*} \text { service vouchers with } \\
\text { tax deduction }\end{array}$ & & & -0.508 & 0.293 \\
\hline $\begin{array}{l}\text { Informal worker * service vouchers without } \\
\text { tax deduction }\end{array}$ & & & -0.381 & 0.287 \\
\hline $\begin{array}{l}\text { Not employing worker }{ }^{*} \text { service vouchers with } \\
\text { tax deduction }\end{array}$ & & & -0.321 & 0.203 \\
\hline $\begin{array}{l}\text { Not employing worker * service vouchers } \\
\text { without tax deduction }\end{array}$ & & & -0.350 & 0.194 \\
\hline
\end{tabular}

Conditional logit model; coefficients and S.E. reported.

$n=8715$ (choices made by 376 respondents).

Control attributes (not reported here): Language (4 levels); Ethnicity (4 levels); Age (3 levels).

Significance: ${ }^{* *} p<0.01,{ }^{* * *} p<0.001$.

$\mathrm{ASC}=$ alternative specific constant.

policy on the informal use of home repairs, an activity that is not subsidized by the voucher system in Belgium. This test confirms the validity of our estimates since no effect is observed where no effect is to be expected.

\subsection{Households prefer formal employment}

The discrete choice experiment allows us to test whether households on average prefer formal over informal employment (hypothesis 2a) and whether this effect also applies to households employing a domestic worker informally (hypothesis 2b). We also estimate the respondents' willingness to pay for the difference in employment status. Table 3 presents the result of the conditional logit model. The ASCs show that respondents prefer choosing one of the profiles over opting out. From the coefficient of the price attribute, one can infer that a lower price is preferred over a higher one. As regards the main attribute of interest, the employment status, model 1 shows that respondents favour both service vouchers with and without tax deduction over employing a housekeeper informally. This result confirms hypothesis 2 a. Model 2 introduces interaction effects with the employment situation of the respondent. As the sum of the interaction coefficients with the main effect remains significantly positive (test statistics in 
the appendix, table A2), we infer that employers of an informal domestic worker (and households without PHS) still have a preference for formal employment with service vouchers. This means that hypothesis $2 \mathrm{~b}$ is also confirmed. Furthermore, and not surprising given the result of the price attribute, each group prefers service vouchers with tax deductions over vouchers without tax deduction (test statistics in the appendix, table $\mathrm{A}_{3}$ ).

The conditional logit model allows calculating the willingness-to-pay for given attributes, by dividing the coefficient of the attribute level by the coefficient of the price (see appendix, table $\mathrm{A}_{4}$ ). In our case, respondents who currently employ a formal domestic would be willing to pay a surplus of $€ 14.00$ for a system of service vouchers with a tax deduction and $€ 7.04$ for a voucher system without deduction, instead of hiring a housekeeper informally. Respondents who currently employ a domestic worker informally, are willing to pay $€ 10.08$ for a system with deduction and $€ 4$.10 for a voucher system without deduction. This captures the central conclusion regarding hypothesis 2 well: even informal employers have a positive willingness to pay for formal employment status.

Although stated willingness-to-pay calculations tend to overestimate the willingness to pay in real life (List and Gallet, 2001; Little and Berrens, 2004), the indication that customers are prepared to pay a premium to hire a housekeeper formally, even those customers that currently employ a domestic informally, is more important in our context. Currently, the Belgian government spends a large amount to subsidize the system and keep the price on the market artificially low, to allow it to compete with the informal market. This aim most probably is met: the average hourly wage reported by employers of informal domestic workers $(\overline{\mathrm{X}}=10.2 ; \mathrm{SD}=1.6)$ makes it safe to infer that the informal hourly wage exceeds the gross hourly cost under the service voucher scheme ( $€ 9$ before tax deduction). Our results imply that it could in fact allow the legal market to charge a moderate premium in return for the advantages formal employment entails.

\subsection{Informal employers intend to switch employment status}

Finally, we test the prediction from hypothesis 3 : in case of new hiring of a domestic worker, informal employers intend to change the employment status. If verified, the results bring in support for the expectation of a further decline of informal employment under the current policy regime, at the rhythm of turnover of informal domestic workers. Respondents were asked how likely it was that they would organize employment according to the same employment status as the current employment. We tested whether the repeat intention indeed receives a lower score in informal employers, under control of the satisfaction with the actual domestic worker. 
TABLE 4. Regression of the repeat intention of employment status

\begin{tabular}{lcc}
\hline & Coefficient & S.E. \\
\hline Informal employment & $-0.542^{* *}$ & 0.199 \\
Satisfaction & 0.114 & 0.059 \\
$\mathrm{R}^{2}$ & 0.083 & \\
\hline
\end{tabular}

OLS regression with robust standard errors; coefficients reported. $n=273$.Control variables (not reported): Educational level; Age; Gender; Activity rate (non-active, one or two partners active); Household size. Significance: ${ }^{* *} p<0.01$.

The results in Table 4 support the hypothesis. If a household employs a domestic worker informally, this increases the probability that they will switch employment status if a new domestic worker were to be hired. We controlled for the general satisfaction with the domestic worker, allowing us to isolate the effect of informal employment status on the repeat intention, net of the degree of satisfaction with the actual worker. This result further supports the outcome of the stated choice experiment, in particular the test of hypothesis $2 b$, that informal employers prefer formal employment. To the extent that the employment status is detached from the actual and personal relationship with the domestic worker they employ, employers of an informal employee indeed prefer a formal status. As a further exploration, we tested whether informal employers have long-running relationships with their domestic workers. That seems to be the case: informal domestic workers have significantly higher seniority than formal ones (Welch's $t$-test $=4.2 ; p=0.002$ ). Although alternative explanations might be brought forward, this certainly is consistent with the thesis that the personal relationship with the actual domestic worker (partially) accounts for the stickiness of informal employment.

\section{Conclusion and discussion}

This contribution started from two central predictions of the Portes model accounting for informal employment. First, the model predicts that differences in price and search cost between the formal and the informal sector affect their size. Second, social relationships play a significant role in enabling informal transactions. We document whether the predictions are relevant in the market of personal household services (PHS). The Belgian service voucher scheme, with its considerable wage and matching subsidies, indeed is effective in reducing informal employment in the activities covered by the scheme. This analysis of purchases of informal PHS is built on survey data covering all European Union member states. The placebo test validates the finding. This is in line with 
the prediction based on the Portes model: the lack of a price advantage of informal PHS will, ceteris paribus, lead to lower informality. Also, households in general, and even households employing an informal worker, prefer formal over informal employment. We argue that the persistence of demand for informal employment should then be based on differences in social relationships. In particular, strong bonds between households and their informal workers account for the stickiness of informal domestic employment relations. These relations tend to be of a more personal, trust-laden, and intimate nature than many other service relationships. This is amongst others due to the private nature of the relationship, with domestic workers being active in the privacy of one's home. The inference then would be that existing relationships are not swiftly changed, even under a general preference for formal employment and considerable wage subsidies.

The policy conclusion of this contribution is, first and foremost, that it is hard to understate the effectiveness of the service voucher policy. Earlier research indicates substantial employment effects. Our research makes it credible that these effects are partially attributable to the formalization of jobs. This is no small feat: formal workers have access to a pension scheme, benefits in case of work accidents, illness or disability, and so forth.

Further, we should point to the strong indications that households have no preference for informal employment. There is little reason to assume this is limited to PHS. This does not preclude that households develop a legitimation of their hiring of an informal employee (see e.g. Hondagneu-Sotelo, 1997). It does mean that, all things being equal, households on average prefer formal employment. Our analysis indicates that this even applies to informal employers. This can be inferred from the choice experiment but is also supported by the overall preference of informal employers to hire a domestic worker formally, in the case of turnover.

A second conclusion is that the support for the social relationship hypothesis teaches us that the service voucher scheme, and maybe even formalization policies in general, require more time to the extent that an employment relationship is personal, and turnover is lower. It, therefore, is reasonable to expect, under a sustained service voucher policy, a further decline of informal employment among domestic workers. One could even argue, based on the results of our discrete choice experiment, that households are on average willing to pay a surplus for formal employment. To substantiate this conjecture, future research needs to document the willingness to pay for formal domestic work, also in cases where one can observe a revealed preference, in particular where the cost of buying services formally exceeds the informal ones.

\section{Conflict of Interest}

The authors have no conflicts of interest to declare that are relevant to the content of this article. 


\section{Acknowledgements}

The authors received project funding from the Brussels-Capital Region - Innoviris for the research.

\section{References}

Abrantes, M. (2014), 'What about the numbers? A quantitative contribution to the study of domestic services in Europe', International Labour Review, 153: 2, 223-243.

Adriaenssens, S. and Hendrickx, J. (2015), 'Can informal economic activities be explained by social and institutional factors? A comparative analysis', Socio-Economic Review, 13: 4, 627-649.

Adriaenssens, S., Verhaest, D. and Hendrickx, J. (2015), 'Lineland and the underground economy: The multidimensionality of informal work by secondary education students', in A. Mica, J. Winczorek and R. Wiśniewski (eds.), Sociologies of formality and informality. Oxford: Peter Lang.

Andersen, J. (2020), 'The scope of possibilities for user influence in Norwegian municipal care services', Journal of Social Policy, 1-19.

Allingham, M.G. and Sandmo, A. (1972), 'Income tax evasion: a theoretical analysis', Journal of Public Economics, 1: 3-4, 323-338.

Angrist, J. and Pischke, J.-S. (2009), Mostly harmless econometrics. An empiricist's companion, Princeton: Princeton University Press.

Annen, K. (2013), 'Social capital as a substitute for formality: Evidence from Bolivia', European Journal of Political Economy, 31: 0, 82-92.

Belgische Kamer van Volksvertegenwoordigers (2000-2001), Wetsontwerp tot bevordering van buurtdiensten en -banen/Projet de loi visant à favoriser le développement de services et d'emplois de proximité, Parl.St.

Bosmans, K., Mousaid, S., De Cuyper, N., Hardonk, S., Louckx, F. and Vanroelen, C. (2016), 'Dirty work, dirty worker? Stigmatisation and coping strategies among domestic workers', Journal of Vocational Behavior, 92, 54-67.

Card, D., Kluve, J. and Weber, A. (2010), 'Active Labour Market Policy evaluations: A meta-analysis', The Economic Journal, 120: 548, F452-F477.

ChoiceMetrics (2014), Ngene 1.1.2 User Manual \& Reference Guide, Australia.

Craig, L. and Baxter, J. (2016), 'Domestic outsourcing, housework shares and subjective time pressure: Gender differences in the correlates of hiring help', Social Indicators Research, 125: 1, 271-288.

de Ruijter, E., Treas, J.K. and Cohen, P.N. (2005), 'Outsourcing the gender factory: living arrangements and service expenditures on female and male tasks', Social Forces, 84: 1, 305-322.

Defourny, J., Henry, A., Nassaut, S. and Nyssens, M. (2010), 'Does the mission of providers matter on a quasi-market? The case of the Belgian 'service voucher' scheme', Annals of Public and Cooperative Economics, 81: 4, 583-610.

Deidda, M., Di Liberto, A., Foddi, M. and Sulis, G. (2015), 'Employment subsidies, informal economy and women's transition into work in a depressed area: evidence from a matching approach', IZA Journal of Labor Policy, 4: 1, 7.

Desiere, S. and Goesaert, T. (2019), The employment effect of the Belgian service voucher scheme, in C. f. S. Research (ed.) SPSW Working Paper Series, Leuven: KU Leuven.

Devetter, F.-X. and Rousseau, S. (2009), 'The impact of industrialization on paid domestic work: the case of France', European Journal of Industrial Relations, 15: 3, 297-316.

Devetter, F.-X. and Jany-Catrice, F. (2012), 'L'invention d'un secteur et ses conséquences socio-économiques : les politiques de soutien aux services à la personne ', Politiques et management public, 27: 2, 76-99. 
Estévez-Abe, M. and Hobson, B. (2015), 'Outsourcing domestic (care) work: The politics, policies, and political economy', Social Politics: International Studies in Gender, State \& Society, 22: 2, 133-146.

European Commission (2013a), Undeclared work in the European Union, Brussels: European Commission.

European Commission (2013b), Developing personal and household services in the EU: A focus on housework activities, Luxembourg: Publications Office of the European Union.

Farvaque, N. (2015), Thematic review on personal and household services, in S. A. a. I. DG Employment (ed.), Luxembourg: ORSEU.

Feige, E. L. (1990), 'Defining and estimating underground and informal economies: the new institutional economics approach', World development, 18: 7, 989-1002.

Fisman, R. and Wei, S.-J. (2004), 'Tax rates and tax evasion: Evidence from 'missing imports' in China', Journal of Political Economy, 112: 2, 471-496.

Floridi, A., Demena, B.A. and Wagner, N. (2020), 'Shedding light on the shadows of informality: A meta-analysis of formalization interventions targeted at informal firms', Labour Economics, 67, 101925.

Gerard, M., Romainville, J.-F. and Valsamis, D. (2014), Evaluatie van het stelsel van de dienstencheques voor buurtdiensten en -banen 2013. Eindrapport, Brussel: Federale Overheidsdienst Werkgelegenheid, Arbeid en Sociaal Overleg.

Godin, M. (2013), 'Domestic work in Belgium: crossing boundaries between informality and formality', in A. Triandafyllidou (ed.), Irregular migrant domestic workers in Europe: who cares?, London: Routledge.

Hobson, B., Hellgren, Z. and Serrano, I. (2018), 'Migrants, markets and domestic work: Do institutional contexts matter in the personal household service sector?', Journal of European Social Policy, 28: 4, 386-401.

Hondagneu-Sotelo, P. (1997), 'Affluent players in the informal economy: Employers of paid domestic workers', The International Journal of Sociology and Social Policy, 17: 3/4, 130-158.

ILO (2013), Domestic workers across the world: global and regional statistics and the extent of legal protection, Geneva: ILO.

Kleck, G. and Roberts, K. (2012), 'What survey modes are most effective in eliciting self-reports of criminal or delinquent behavior?', in L. Gideon (ed.), Handbook of Survey Methodology for the Social Sciences, New York, NY: Springer New York.

Kornrich, S. and Roberts, A. (2018), 'Household income, women's earnings, and spending on household services, 1980-2010', Journal of Marriage and Family, 80: 1, 150-165.

Kvist, E. (2012), 'Changing social organizations of care: a comparison of European policy reforms encouraging paid domestic work', European Journal of Ageing, 9: 2, 111-117.

Lavallée, P. (2007), Indirect sampling, New York: Springer.

Ledoux, C., Encinas de Muñagorri, R. and Guiraudon, V. (2021), 'Becoming an organised actor in a welfare market: Employers in the French in-home domestic/care services sector', in C. Ledoux, K. Shire and F. van Hooren (eds.), The dynamics of welfare markets: Private pensions and domestic/care services in Europe, Cham: Springer International Publishing.

Leduc, E. and Tojerow, I. (2020), Subsidizing domestic services as a tool to fight unemployment: Effectiveness and hidden costs, IZA Discussion Paper Series, Bonn: IZA.

Lindström, M. (2005), 'Social capital, the miniaturisation of community and consumption of homemade liquor and smuggled liquor during the past year. A population-based study', European Journal of Public Health, 15: 6, 593-600.

List, J. A. and Gallet, C.A. (2001), 'What experimental protocol influence disparities between actual and hypothetical stated values?', Environmental and Resource Economics, 20: 3, 241-254.

Little, J. and Berrens, R. (2004), 'Explaining disparities between actual and hypothetical stated values: further investigation using meta-analysis', Economics Bulletin, 3: 6, 1-13.

Loayza, N. V. (1996), 'The economics of the informal sector: a simple model and some empirical evidence from Latin America', Carnegie-Rochester Conference Series on Public Policy, 45, 129-162. 
Louviere, J.J. and Hensher, D.A. (1982), 'On the design and analysis of simulated choice or allocation experiments in travel choice modelling', Transportation research record, 890: $1,11-17$.

Lutz, H. and Palenga-Möllenbeck, E. (2010), 'Care work migration in Germany: Semi-compliance and complicity', Social Policy and Society, 9: 3, 419-430.

Marion, J. and Muehlegger, E. (2008), 'Measuring illegal activity and the effects of regulatory innovation: Tax evasion and the dyeing of untaxed diesel', Journal of Political Economy, 116: 4, 633-666.

Marx, I. and Vandelannoote, D. (2015), 'Matthew runs amok: The Belgian service voucher scheme', in C. Carbonnier and N. Morel (eds.), The political economy of household services in Europe, Basingstoke: Palgrave-Macmillan.

Morel, N. (2015), 'Servants for the knowledge-based economy? The political economy of domestic services in Europe', Social Politics: International Studies in Gender, State \& Society, 22: 2, 170-192.

Pacolet, J., De Wispelaere, F. and Cabus, S. (2010), Bomen groeien niet tot in de hemel: De werkelijke kostprijs van de dienstencheques, Leuven: HIVA.

Peeters, A., Van Pelt, A. and Valsamis, D. (2008), Evaluatie van het stelsel van de dienstencheques voor buurtdiensten en -banen 2007, Brussel: Federale Overheidsdienst Werkgelegenheid, Arbeid en Sociaal Overleg.

Peeters, A., Van Pelt, A. and Valsamis, D. (2009), Evaluatie van het stelsel van de dienstencheques voor buurtdiensten en -banen 2008, Brussel: Federale Overheidsdienst Werkgelegenheid, Arbeid en Sociaal Overleg.

Pisani, M. J. (2005), 'Grass, sweat and sun: an exploratory study of the labor market for gardeners in South-Texas', Social Science Quarterly, 86: 1, 229-251.

Pisani, M. J., Richardson, C. and Patrick, J. M. (2008), 'Economic informality on the U.S.-Mexican border: A (re)view from South Texas', Journal of Borderlands Studies, 23: 2, 19-40.

Polanyi, K. (1957), 'The economy as instituted process', in K. Polanyi and C. M. Arensberg (eds.), Trade and market in the early empires. Economies in history and theory, Glencoe: Free Press.

Portes, A. (1994), 'The informal economy and its paradoxes', in N. J. Smelser and R. Swedberg (eds.), The handbook of economic sociology, Princeton: Princeton University Press.

Portes, A. (2010), Economic sociology: a systematic inquiry, Princeton: Princeton University Press.

Portes, A. and Haller, W. (2005), 'The informal economy', in N. J. Smelser and R. Swedberg (eds.), The handbook of economic sociology, Princeton: Princeton University Press.

Prado, M. (2011), 'Government policy in the formal and informal sectors', European Economic Review, 55, 1120-1136.

Raz-Yurovich, L. and Marx, I. (2018), 'What does state-subsidized outsourcing of domestic work do for women's employment? The Belgian service voucher scheme', Journal of European Social Policy, 28: 2, 104-115.

Raz-Yurovich, L. and Marx, I. (2019), 'Outsourcing housework and highly skilled women's labour force participation-An analysis of a policy intervention', European Sociological Review.

Rose, J. M., Bliemer, M. C. J., Hensher, D. A. and Collins, A. T. (2008), 'Designing efficient stated choice experiments in the presence of reference alternatives', Transportation Research Part B: Methodological, 42: 4, 395-406.

Schooreel, T. and Valsamis, D. (2017), Evaluatie van het stelsel van de dienstencheques voor buurtbanen en -diensten in het Brussels Hoofdstedelijk Gewest, 2014 en 2015, Brussel: Gewestelijke Overheidsdienst Brussel Economie en Werkgelegenheid, Dienst Werkgelegenheid.

Theys, T., Adriaenssens, S., Verhaest, D., Deschacht, N. and Rousseau, S. (2020), 'Disentangling language from ethnic preferences in the recruitment of domestic workers: A discrete choice experiment', Journal of Business Research, 117, 144-151.

White, R. J. and Williams, C. C. (2016), 'Beyond capitalocentricism: are non-capitalist work practices 'alternatives'?', Area, 48: 3, 325-331. 
Williams, C. C. (2018), Elements of a preventative approach towards undeclared work: an evaluation of service vouchers and awareness raising campaigns, European Platform Undeclared Work, Luxembourg: European Commission.

Windebank, J. (2007), 'Outsourcing women's domestic labour: the Chèque Emploi-Service Universel in France', Journal of European Social Policy, 17: 3, 257-270.

Yitzhaki, S. (1974), 'A note on income tax evasion: A theoretical analysis', Journal of Public Economics, 3: 2, 201-202.

\section{Appendix}

TABLE A1. Conditional logit model - full results (hypothesis 2)

\begin{tabular}{|c|c|c|c|c|}
\hline & \multicolumn{2}{|c|}{ Model 1} & \multicolumn{2}{|c|}{ Model 2} \\
\hline & Coefficient & S.E. & Coefficient & S.E. \\
\hline \multicolumn{5}{|l|}{ Employment status (ref.: informal employment) } \\
\hline Service vouchers with tax deduction & $1.669^{* * * *}$ & 0,105 & $1.814^{* * * *}$ & 0.132 \\
\hline Service vouchers without tax deduction & $0.777^{* * *}$ & 0,099 & $0.912^{* * *}$ & 0.122 \\
\hline \multicolumn{5}{|l|}{ Language (ref.: native language) } \\
\hline Non-native country language & $-1.168^{* * *}$ & 0.077 & $-1.172^{* * *}$ & 0.077 \\
\hline English & $-0.994^{* * *}$ & .101 & $-0.996^{* * *}$ & 0.101 \\
\hline No communication & $-2.720^{* * *}$ & 0.151 & $-2.730^{* * *}$ & 0.150 \\
\hline \multicolumn{5}{|l|}{ Age (ref.: 35) } \\
\hline 20 & $-0.513^{* * * *}$ & 0.078 & $-0.519^{* * * *}$ & 0.078 \\
\hline 35 & $-0.492^{* * *}$ & 0.074 & $-0.495^{* * *}$ & 0.074 \\
\hline \multicolumn{5}{|l|}{ Ethnicity (ref.: Flemish) } \\
\hline Maghreb & $-0.594^{* * *}$ & 0.099 & $-0.598^{* * *}$ & 0.099 \\
\hline Polish & -0.166 & 0.110 & -0.173 & 0.110 \\
\hline Walloon & -0.079 & 0.103 & -0.082 & 0.103 \\
\hline Price & $-0.129^{* * * *}$ & 0,012 & $-0.130^{* * *}$ & 0.012 \\
\hline ASC 1 & $1.492^{* * *}$ & 0,164 & $1.505^{* * *}$ & 0.163 \\
\hline $\operatorname{ASC}_{2}$ & $1.535^{* * *}$ & 0,178 & $1.548^{* * *}$ & 0.177 \\
\hline \multicolumn{5}{|l|}{$\begin{array}{l}\text { Interaction effects (ref.: currently employing a } \\
\text { formal domestic) }\end{array}$} \\
\hline $\begin{array}{l}\text { Employing an informal domestic * service vouchers } \\
\text { with tax deduction }\end{array}$ & & & -0.508 & 0.293 \\
\hline $\begin{array}{l}\text { Employing an informal domestic * service vouchers } \\
\text { without tax deduction }\end{array}$ & & & -0.381 & 0.287 \\
\hline $\begin{array}{l}\text { Not employing a domestic * service vouchers with tax } \\
\text { deduction }\end{array}$ & & & -0.321 & 0.203 \\
\hline $\begin{array}{l}\text { Not employing a domestic * service vouchers without } \\
\text { tax deduction }\end{array}$ & & & -0.350 & 0.194 \\
\hline
\end{tabular}

Conditional logit model; coefficients and S.E. reported.

$n=8715$ (choices made by 376 respondents).

Control attributes (not reported here): Language (4 levels); Ethnicity (4 levels); Age (3 levels) Significance: ${ }^{* *} p<0.01,{ }^{* * *} p<0.001$.

ASC $=$ alternative specific constant. 
TABLE A2. Results of Wald $\mathrm{Chi}^{2}$-tests testing significance of preference for vouchers with and without deduction for households with an informal domestic and households not employing a domestic

\begin{tabular}{|c|c|c|c|c|}
\hline & Coefficient & Wald & Chi-square(1) & $\mathrm{p}$-value \\
\hline \multicolumn{5}{|l|}{ Vouchers with deduction } \\
\hline $\begin{array}{l}\text { Main effect + interaction effect household } \\
\text { currently employing an informal domestic }\end{array}$ & 1.31 & & 22.86 & 0.000 \\
\hline $\begin{array}{l}\text { Main effect }+ \text { interaction effect household } \\
\text { currently not employing a domestic }\end{array}$ & 1.49 & & 78.55 & 0.000 \\
\hline \multicolumn{5}{|l|}{ Vouchers without deduction } \\
\hline $\begin{array}{l}\text { Main effect + interaction effect household } \\
\text { currently employing an informal domestic }\end{array}$ & 0.53 & & 4.04 & 0.044 \\
\hline $\begin{array}{l}\text { Main effect }+ \text { interaction effect household } \\
\text { currently not employing a domestic }\end{array}$ & 0.56 & & 11.67 & 0.001 \\
\hline
\end{tabular}

TABLE A3. Results of Wald $\mathrm{Chi}^{2}$-tests testing significance of preference for vouchers with tax deduction over vouchers without tax deduction for households with a formal or informal domestic and households not employing a domestic

Coefficient Wald Chi-square(1) p-value

Preference for vouchers with tax deduction over vouchers without tax deduction Households with a formal domestic Households with an informal domestic Households currently not employing

$\begin{array}{lrl}0.90 & 63.73 & 0.000 \\ 0.77 & 8.80 & 0.003 \\ 0.93 & 38.91 & 0.000\end{array}$
a domestic

TABLE A4. Willingness to pay for service vouchers with and without tax deduction, in comparison to informal employment

\begin{tabular}{|c|c|c|c|}
\hline & $\begin{array}{l}\text { Willingness } \\
\text { to pay }(€)\end{array}$ & $\begin{array}{l}\text { Upper bound } \\
(€)\end{array}$ & $\begin{array}{c}\text { Lower bound } \\
(€)\end{array}$ \\
\hline \multicolumn{4}{|c|}{ Households employing a formal domestic } \\
\hline Service vouchers with tax deduction & 14.00 & 17.02 & 10.98 \\
\hline Service vouchers without tax deduction & 7.04 & 9.27 & 4.82 \\
\hline \multicolumn{4}{|c|}{ Households employing an informal domestic } \\
\hline Service vouchers with tax deduction & 10.08 & 14.67 & 5.49 \\
\hline Service vouchers without tax deduction & 4.10 & 8.17 & 0.04 \\
\hline \multicolumn{4}{|c|}{ Households currently not employing a domestic } \\
\hline Service vouchers with tax deduction & 11.16 & 14.08 & 8.24 \\
\hline Service vouchers without tax deduction & 4.28 & 6.49 & 2.07 \\
\hline
\end{tabular}

Willingness-to-pay $=$ attribute level coefficient/price coefficient.

Confidence intervals (95\%) are calculated using the Delta method. 